\title{
Challenges before International Commercial Arbitration in India and new hope for its improvements under the Arbitration and Conciliation (Amendment) Act, 2015: An analysis
}

\author{
${ }^{1}$ Prof. (Dr.) Rajesh Bahuguna ${ }^{2}$ Vijay Srivastava \\ Challenges before International Commercial Arbitration in India and new hope for its improvements under \\ The Arbitration and Conciliation (Amendment) Act, 2015: An analysis
}

\begin{abstract}
Arbitral Awards, Choice of law, Commercial Disputes, Conflict of law, Procedural law, Seat of arbitration, etc.

In International trade and commerce, every commercial activity is generally preceded by a contract fixing the obligations of the parties to avoid legal disputes. But in this, No matter how carefully a contract is drafted, one party to the contract may understand his right and obligations in a different way. Often international trade involves traders belonging to different countries whose legal systems may differ in many ways to that of the other, presenting complicated and even conflicting features. The law courts of each country have jurisdiction only within the territorial limits of the concerned country. Therefore, arbitration came to be preferred as an effective means of resolving disputes between the parties belonging to different nations.

A disputes resolution system, which is commercial in nature and involving an international element, it gets termed as "International Commercial Arbitration". Meaning thereby, in International Commercial Arbitration, one of the party is a resident of any country other than India or a body corporate which is incorporated in any country other than India or a Company or an Association or a body of an individuals whose central management and control is exercised in any country other than India or the Government of a foreign country and when any dispute which is arises from commercial relations amongst these parties, if such disputes are referred for settlement through Arbitration, it is known as International Commercial Arbitration.
\end{abstract}

KEY WORDS: International commercial arbitration, UNCITRAL, cross border Trade

\section{Introduction}

India has effectively grown-up and acquired importance as a rapidly advancing economic power, and securing its position as an important player in international trade and commerce. It is vital that our arbitration practices and laws, while continuing to cater to the specific needs of the Indian citizenry, are at par with the best practices established across the world. Pertinently, the Arbitration and Conciliation Act, 1996, traces its genesis to the UNCITRAL Model Law, which encompasses globally accepted standards for arbitration proceedings. Procedural aspects of International Commercial Arbitration differ significantly amongst the different countries of the world, because, International commercial arbitration today, is ever more transnational and multijurisdictional. Pertinently, the Arbitration and Conciliation Act, 1996, of India traces its genesis to the UNCITRAL Model Law, which encompasses globally accepted standards for arbitration proceedings

This research aims to discuss, mainly by way of a comparative analysis, of some of the crucial and relevant practices governing arbitration in following jurisdictions -China, Hong Kong, the United States, South Africa, Singapore United Kingdom etc. The objective of this comparative study is to identify and understand the strengths and weaknesses of the arbitration law and practice prevalent in these jurisdictions, and ultimately use the insights gleaned to critique our own laws and using this critical analysis, hopefully, incorporate stronger and

\footnotetext{
${ }^{1}$ Dean \& Principal, College of Law, Uttaranchal University, Dhradun, Uttarakhand, India

${ }^{2}$ Assistant Professor, College of Law, Uttaranchal University, Dhradun, Uttarakhand, India

DOI: 10.9790/0837-2204023245 $\quad$ www.iosrjournals.org $32 \mid$ Page
}


better practices within the Indian arbitration regime. In this regard, consider the examples set by England and Singapore - both have successfully honed and developed their arbitration laws and practices to become the preferred destinations for international commercial arbitrations, so much so that they are relied upon increasingly even by Indian users (outside of India), and also for foreign users seeking to arbitrate with Indian parties. Is this a fair appraisal of the present scenario? What are the lessons that India can learn from the practices and policies deployed in these jurisdictions?

A crucial issue in this respect is the role of the judiciary in supplementing the alternative dispute resolution framework. Discussions in this regard should ultimately consider India's potential to emerge as a globally preferred centre of arbitration.

\section{Certain basic differential ICA issues between Indian Arbitration law and other countries arbitration system;}

BASIS-1-

\begin{tabular}{|c|c|}
\hline & Basis for difference: \\
\hline & Commencement of arbitration proceedings \\
\hline $\begin{array}{l}\text { Provisions under } \\
\text { UNCITRAL } \\
\text { LAW }\end{array}$ & $\begin{array}{l}\text { As per the Article } 3(2) \text { Arbitral proceedings deemed to have commenced of } \\
\text { the date the respondent receives a written notice of arbitration from the } \\
\text { claimant. }\end{array}$ \\
\hline $\begin{array}{l}\text { Provisions } \\
\text { Law under } \\
\text { Arbitration Law }\end{array}$ & $\begin{array}{l}\text { As per the section } 21 \text { of the Arbitration and conciliation Act, } 1996 \text { Arbitral } \\
\text { proceedings deemed to have commenced of the date the when it is received } \\
\text { by the other party. }\end{array}$ \\
\hline $\begin{array}{l}\text { Provisions under } \\
\text { Hongkong } \\
\text { Arbitration Law }\end{array}$ & $\begin{array}{l}\text { As per the HKIAC Article } 4.2 \text {. Arbitration deemed to start at date notice of } \\
\text { Arbitration is received by the HKIAC secretariat. }\end{array}$ \\
\hline $\begin{array}{l}\text { Provisions under } \\
\text { Singapore } \\
\text { Arbitration Law }\end{array}$ & $\begin{array}{l}\text { As per the SIAC rules 1.1. a party wishing to commence arbitration must file } \\
\text { a notice of arbitration with the Registrar. }\end{array}$ \\
\hline $\begin{array}{l}\text { Provisions under } \\
\text { South African } \\
\text { Arbitration Law }\end{array}$ & $\begin{array}{l}\text { As per the S.A. arbitration law ,Article } 1.2 \text { The date of receipt by the } \\
\text { registrar of the Request for Arbitration } \\
\text { shall be treated as the date on which the } \\
\text { arbitration has commenced }\end{array}$ \\
\hline $\begin{array}{l}\text { Provisions under } \\
\text { China } \\
\text { Arbitration Law }\end{array}$ & $\begin{array}{l}\text { As per the Article } 3(2) \text { Arbitral proceedings deemed to have commenced of } \\
\text { the date the respondent receives a written notice of arbitration from the } \\
\text { claimant. }\end{array}$ \\
\hline $\begin{array}{l}\text { Provisions under } \\
\text { U.S.A. } \\
\text { Arbitration Law }\end{array}$ & $\begin{array}{l}\text { Rule 3.1: A party wishing to commence arbitration must file a Notice of } \\
\text { Arbitration with the Registrar. }\end{array}$ \\
\hline
\end{tabular}

\section{BASIS- 2-}

\begin{tabular}{|l|l|}
\hline & Basis for difference: \\
\hline & \multicolumn{1}{c|}{ Seat for Arbitration } \\
\hline $\begin{array}{l}\text { Provisions } \\
\text { under } \\
\text { UNCITRAL }\end{array}$ & $\begin{array}{l}\text { Article 18(1): Unless the parties have agreed upon the place where the arbitration } \\
\text { is to be held, the place of arbitration shall be determined by the Arbitral Tribunal. }\end{array}$ \\
\hline
\end{tabular}




\begin{tabular}{|c|c|}
\hline LAW & \\
\hline $\begin{array}{l}\text { Provisions } \\
\text { under Law } \\
\text { Indian } \\
\text { Arbitration } \\
\text { Law }\end{array}$ & $\begin{array}{l}\text { As per the section } 20 \text { of the Arbitration and conciliation Act, } 1996 \text { parties are free to } \\
\text { choose the seat for arbitration }\end{array}$ \\
\hline $\begin{array}{l}\text { Provisions } \\
\text { under } \\
\text { Hongkong } \\
\text { Arbitration } \\
\text { Law }\end{array}$ & $\begin{array}{l}\text { HKIAC Article 15.1: The seat of all arbitrations conducted under the } \\
\text { HKIAC Rules is the Hong Kong Special Administrative Region of the People's } \\
\text { Republic of China. }\end{array}$ \\
\hline $\begin{array}{l}\text { Provisions } \\
\text { under } \\
\text { Singapore } \\
\text { Arbitration } \\
\text { Law }\end{array}$ & $\begin{array}{l}\text { Rule 18.1: The parties may agree the seat of arbitration. Failing such an agreement, } \\
\text { the seat of arbitration shall be in Singapore, unless the Tribunal determines, having } \\
\text { regard to all of the circumstances of the case, that another seat is more appropriate. }\end{array}$ \\
\hline $\begin{array}{l}\text { Provisions } \\
\text { under Sauth } \\
\text { African } \\
\text { Arbitration } \\
\text { Law }\end{array}$ & $\begin{array}{l}\text { Article 14(1): The place of the Arbitration shall be fixed by the Court, unless it has } \\
\text { been agreed by the parties. }\end{array}$ \\
\hline $\begin{array}{l}\text { Provisions } \\
\text { under } \\
\text { China } \\
\text { Arbitration } \\
\text { Law }\end{array}$ & $\begin{array}{l}\text { Rule 4: The Director of the KLRCA shall, at the request or either party, make or } \\
\text { arrange such facilities and assistance for the conduct of the Arbitral Tribunal. }\end{array}$ \\
\hline $\begin{array}{l}\text { Provisions } \\
\text { under } \\
\text { U.S.A. } \\
\text { Arbitration } \\
\text { Law }\end{array}$ & $\begin{array}{l}\text { Article 16: The parties may agree in writing the seat (or legal place) of the } \\
\text { arbitration. If the parties fail to agree the seat of arbitration, the seat of the } \\
\text { arbitration shall be London. }\end{array}$ \\
\hline
\end{tabular}

\section{BASIS- 3-}

\begin{tabular}{|l|l|}
\hline & Basis for difference: \\
\hline $\begin{array}{l}\text { Provisions } \\
\text { under } \\
\text { UNCITRAL } \\
\text { LAW }\end{array}$ & $\begin{array}{l}\text { Law applied } \\
\text { parties, failing such agreement the Tribunal shall apply the law which it } \\
\text { determines to be appropriate. }\end{array}$ \\
\hline $\begin{array}{l}\text { Provisions } \\
\text { under Law } \\
\text { Indian } \\
\text { Arbitration } \\
\text { Law }\end{array}$ & $\begin{array}{l}\text { As per the provisions of section 28(2)\& 28 (3) the Arbitration and conciliation } \\
\text { Act, 1996 the arbitral tribunal shall decide on the principles of ex aequo et } \\
\text { bono as amicable compsiteur only if the parties have expressly authorized to }\end{array}$ \\
$\begin{array}{l}\text { Provisions } \\
\text { under } \\
\text { Hongkong } \\
\text { Arbitration }\end{array}$ & $\begin{array}{l}\text { HKIAC Article 31.1: The Arbitral Tribunal shall apply the rules of law chosen } \\
\text { by the parties, failing such agreement the Tribunal shall determine the law of the } \\
\text { dispute which it determines to be appropriate. }\end{array}$ \\
\hline
\end{tabular}




\begin{tabular}{|l|l|}
\hline Law & \\
\hline $\begin{array}{l}\text { Provisions } \\
\text { under } \\
\text { Singapore } \\
\begin{array}{l}\text { Arbitration } \\
\text { Law }\end{array}\end{array}$ & $\begin{array}{l}\text { Rule 27.1: The Tribunal shall apply the rules of law designated by the parties as } \\
\text { applicable to the substance of dispute. Failing such designation by the parties, } \\
\text { the Tribunal shall apply the law which it determines to be appropriate. }\end{array}$ \\
\hline $\begin{array}{l}\text { Provisions } \\
\text { under Sauth } \\
\text { African }\end{array}$ & $\begin{array}{l}\text { Article 17(1): If not agreed by the parties, the Arbitral Tribunal shall apply the } \\
\text { rules of law that it determines appropriate. }\end{array}$ \\
\hline $\begin{array}{l}\text { Law } \\
\text { under Chisions } \\
\text { Arbitration } \\
\text { Law }\end{array}$ & $\begin{array}{l}\text { UNCITRAL Article 35(1): The Arbitral Tribunal shall apply the rules of law } \\
\text { chosen by the parties, failing such agreement the Tribunal shall apply the law } \\
\text { which it determines to be appropriate. }\end{array}$ \\
\hline $\begin{array}{l}\text { Provisions } \\
\text { under U.S.A. } \\
\text { Law }\end{array}$ & $\begin{array}{l}\text { Article 16.3: The law applicable to the arbitration (if any) shall be the arbitration } \\
\text { law of the seat of the arbitration, unless the parties have agreed in writing on the } \\
\text { application of another arbitration law and such agreement is not prohibited by } \\
\text { the law of the Arbitral seat. } \\
\text { Article 22.3: The Arbitral Tribunal shall decide the parties dispute based upon } \\
\text { the } \\
\text { law chosen by the parties. Where the parties have not agreed the law to } \\
\text { applied to the dispute, the Arbitral Tribunal shall apply what rules of law it } \\
\text { considers appropriate }\end{array}$ \\
\hline
\end{tabular}

\section{BASIS- 4-}

\begin{tabular}{|l|l|}
\hline & Basis for difference: \\
\hline $\begin{array}{l}\text { Provisions } \\
\text { under } \\
\text { UNCITRAL } \\
\text { LAW }\end{array}$ & $\begin{array}{l}\text { Prticle 27(3): The Arbitral Tribunal may require the parties to produce documents } \\
\text { and other evidence within such a period of time as the Tribunal determines. } \\
\text { Article 27(4): The Arbitral Tribunal shall determine the admissibility, relevance, } \\
\text { materiality and weight of the evidence offered. } \\
\text { Article 30(3): If a party, after invited by the Arbitral Tribunal to produce documents, } \\
\text { exhibits or other evidence, fails to do so within the established period of time, } \\
\text { without showing sufficient cause, the Arbitral Tribunal shall make the award on the } \\
\text { evidence before it. }\end{array}$ \\
\hline $\begin{array}{l}\text { Provisions } \\
\text { under Law } \\
\text { Indian }\end{array}$ & $\begin{array}{l}\text { As per the provisions of section of } 47 \text { \& 56 of the Arbitration and conciliation Act, } \\
\text { 1996, the party applying for the enforcement of a foreign award, at the time of the } \\
\text { application, produce before the court. }\end{array}$ \\
$\begin{array}{l}\text { Provisions } \\
\text { under } \\
\text { Hongkong } \\
\text { Arbitration } \\
\text { Law }\end{array}$ & $\begin{array}{l}\text { HKIAC Article 23.3: At any time during the Arbitral proceedings the Arbitral } \\
\text { Tribunal may require the parties to produce documents or other evidence. The } \\
\text { evidence or other evidence. } \\
\text { HKIAC Article 23.10: The Arbitral Tribunal shall determine the admissibility, } \\
\text { relevance, materiality and weight of any matter and whether or not to apply the strict } \\
\text { rules of evidence. }\end{array}$ \\
\hline
\end{tabular}




\begin{tabular}{|c|c|}
\hline $\begin{array}{l}\text { Provisions } \\
\text { under } \\
\text { Singapore } \\
\text { Arbitration } \\
\text { Law }\end{array}$ & $\begin{array}{l}\text { Rule 16.6: All statements, documents or other information supplied to the Tribunal } \\
\text { by one party shall simultaneously be communicated to the other party. }\end{array}$ \\
\hline $\begin{array}{l}\text { Provisions } \\
\text { under Sauth } \\
\text { African } \\
\text { Arbitration } \\
\text { Law }\end{array}$ & $\begin{array}{l}\text { Article 20(6): The Arbitral Tribunal may } \\
\text { decide the case solely on the documents } \\
\text { submitted by the parties unless any of the } \\
\text { parties requests a hearing. }\end{array}$ \\
\hline $\begin{array}{l}\text { Provisions } \\
\text { under } \\
\text { China } \\
\text { Arbitration } \\
\text { Law }\end{array}$ & $\begin{array}{l}\text { UNCITRAL Article 27(3): The Arbitral Tribunal may require the parties to produce } \\
\text { documents and other evidence within such a period of time as the Tribunal } \\
\text { determines. } \\
\text { UNCITRAL Article 27(4): The Arbitral Tribunal shall determine the admissibility, } \\
\text { relevance, materiality and weight of the evidence offered. } \\
\text { UNCITRAL Article 30(3): If a party, after invited by the Arbitral Tribunal to } \\
\text { produce documents, exhibits or other evidence, fails to do so within the established } \\
\text { period of time, without showing sufficient cause, the Arbitral Tribunal shall make } \\
\text { the award on the evidence before it. }\end{array}$ \\
\hline $\begin{array}{l}\text { Provisions } \\
\text { under } \\
\text { U.S.A. } \\
\text { Arbitration } \\
\text { Law }\end{array}$ & $\begin{array}{l}\text { Article 19.1: The parties may agree in writing to have a documents-only } \\
\text { arbitration. Any party has the right to be heard orally before the Arbitral Tribunal. } \\
\text { Article 15.6: Both the Statement of Case and Response shall be accompanied by } \\
\text { copies of all essential documents upon which the party relies, unless they are too } \\
\text { voluminous, at which point they should be submitted by list. }\end{array}$ \\
\hline
\end{tabular}

BASIS- 5-

\begin{tabular}{|c|c|}
\hline & Basis for difference: \\
\hline & Interim measures \\
\hline $\begin{array}{l}\text { Provisions } \\
\text { under } \\
\text { UNCITRAL } \\
\text { LAW }\end{array}$ & $\begin{array}{l}\text { Article 26(1): At the request of either party the Tribunal may grant interim measures, } \\
\text { including the preservation of assets and maintaining the status quo pending the } \\
\text { determination of the dispute. }\end{array}$ \\
\hline $\begin{array}{l}\text { Provisions } \\
\text { under Law } \\
\text { Indian } \\
\text { Arbitration } \\
\text { Law }\end{array}$ & $\begin{array}{l}\text { As per the provisions of section of } 9 \text { of the Arbitration and conciliation Act, 1996, a } \\
\text { party may apply for interim measures, before or during arbitral proceedings or at any } \\
\text { time after the making of the arbitral award but before it is enforced for appointment of } \\
\text { guardian, for preservation or custody or sale of goods or securing the amount in dispute } \\
\text { or property, for interim injunction or the appointment of a receiver or such other } \\
\text { interim measure of protection as may appear to court to be just and convenient. }\end{array}$ \\
\hline $\begin{array}{l}\text { Provisions } \\
\text { under } \\
\text { Hongkong } \\
\text { Arbitration } \\
\text { Law }\end{array}$ & $\begin{array}{l}\text { HKIAC Article 24.1: At the request of either party the Arbitral Tribunal may order any } \\
\text { interim measures it deems necessary or appropriate. } \\
\text { HKIAC Article 24.4: The Arbitral Tribunal has the discretion to apportion the costs } \\
\text { relating to a request for interim measures in an order, interim award or final award. }\end{array}$ \\
\hline $\begin{array}{l}\text { Provisions } \\
\text { under } \\
\text { Singapore } \\
\text { Arbitration } \\
\text { Law }\end{array}$ & $\begin{array}{l}\text { Rule 26.1: The Tribunal may at the request of a party, issue an order or an award } \\
\text { granting any interim relief it deems appropriate. The Tribunal may order the } \\
\text { party requesting interim relief to provide } \\
\text { appropriate security in connection with the relief sought. }\end{array}$ \\
\hline
\end{tabular}




\begin{tabular}{|c|c|}
\hline $\begin{array}{l}\text { Provisions } \\
\text { under Sauth } \\
\text { African } \\
\text { Arbitration } \\
\text { Law }\end{array}$ & $\begin{array}{l}\text { Article 23(1): Unless the parties have otherwise agreed, as soon as the file has } \\
\text { been transmitted to it, the Arbitral Tribunal may 'order any interim or conservatory } \\
\text { measure it deems appropriate'. }\end{array}$ \\
\hline $\begin{array}{l}\text { Provisions } \\
\text { under } \\
\text { China } \\
\text { Arbitration } \\
\text { Law }\end{array}$ & $\begin{array}{l}\text { UNCITRAL Article 26(1): At the request of either party the Tribunal may grant interim } \\
\text { measures, including the preservation of assets and maintaining the status quo pending } \\
\text { the determination of the dispute. }\end{array}$ \\
\hline $\begin{array}{l}\text { Provisions } \\
\text { under } \\
\text { U.S.A. } \\
\text { Arbitration } \\
\text { Law }\end{array}$ & $\begin{array}{l}\text { Rule 26.1: The Tribunal may at the request of a party, issue an order or an award } \\
\text { granting any interim relief it deems appropriate. The Tribunal may order the party } \\
\text { requesting interim relief to provide appropriate security in connection with the relief } \\
\text { sought. }\end{array}$ \\
\hline
\end{tabular}

BASIS- 6-

\begin{tabular}{|c|c|}
\hline & Basis of difference: \\
\hline & Recourse against arbitral awards \\
\hline $\begin{array}{l}\text { Provisions under } \\
\text { UNCITRAL } \\
\text { LAW }\end{array}$ & $\begin{array}{l}\text { Article 30: If within a period of time fixed by the UNCITRAL Rules or the } \\
\text { Arbitral Tribunal: (1): The Claimant has failed to communicate its Statement of } \\
\text { Claim, the Arbitral Tribunal shall issue and order terminating the Arbitral } \\
\text { proceedings, unless there are other remaining matters, such as a counter claim. } \\
\text { (2): The Respondent has failed to communicate its response to the Notice of } \\
\text { Arbitration or its Statement of Defence, the Arbitral Tribunal shall order the } \\
\text { proceedings to continue, without treating such failure as an admission of the } \\
\text { Claimant's allegations. Article 30(2): If a party, duly notified under the Rules, } \\
\text { fails to appear at a hearing, without showing sufficient cause for such failure, the } \\
\text { Arbitral Tribunal may proceed with the arbitration. Article 30(3): If a party, duly } \\
\text { invited by the Arbitral Tribunal to produce documents, exhibits or other } \\
\text { evidence, fails to do so within the established period of time, without showing } \\
\text { sufficient cause for such failure, the Arbitral Tribunal may make an award on the } \\
\text { evidence before it. }\end{array}$ \\
\hline $\begin{array}{lr}\text { Provisions } & \text { under } \\
\text { Law Indian } \\
\text { Arbitration Law }\end{array}$ & $\begin{array}{l}\text { As per the provisions of section } 34 \text { of the Arbitration and conciliation Act, 1996, } \\
\text { recourse to a court against an arbitral award may be only by an application for } \\
\text { setting aside such award for the given conditions under this section within a } \\
\text { period of one year from the date on which the notice to in sub section (5) served } \\
\text { upon the other party. }\end{array}$ \\
\hline $\begin{array}{l}\text { Provisions under } \\
\text { Hongkong } \\
\text { Arbitration Law }\end{array}$ & $\begin{array}{l}\text { HKIAC Article 26.1: If within a period of time set by the Arbitral Tribunal the } \\
\text { Claimant has failed to communicate its Statement of Claim without showing } \\
\text { sufficient cause for such failure, the Arbitral Tribunal shall issue an order for the } \\
\text { termination of the Arbitral Proceedings unless the Respondent has brought a } \\
\text { counterclaim and wishes the Arbitration to continue. } \\
\text { HKIAC Article 26.1: If, within the period of time set by the Arbitral Tribunal, } \\
\text { the } \\
\text { Respondent has failed to communicate its Statement of Defence without showing } \\
\text { sufficient cause for such failure, the Arbitral Tribunal may proceed with the } \\
\text { Arbitration. }\end{array}$ \\
\hline $\begin{array}{l}\text { Provisions under } \\
\text { Singapore } \\
\text { Arbitration Law }\end{array}$ & $\begin{array}{l}\text { Rule 17.8: If the Claimant fails within the time specified to submit its Statement } \\
\text { of Claim, the Tribunal may issue an order for the termination of the Arbitral } \\
\text { Proceedings or give such other directions as may be appropriate. }\end{array}$ \\
\hline
\end{tabular}




\begin{tabular}{|c|c|}
\hline & $\begin{array}{l}\text { Rule 17.9: If the Respondent fails to submit a Statement of Defence, or if at any } \\
\text { point any party fails to avail itself of the opportunity to present its case in a } \\
\text { manner directed by the Tribunal, the Tribunal may proceed with the arbitration. } \\
\text { Rule 21.3: If any party to the proceedings fails to appear at a hearing without } \\
\text { showing sufficient cause for such failure, the Tribunal may proceed with the } \\
\text { arbitration and may } \\
\text { make the award based on the submissions and evidence before it. }\end{array}$ \\
\hline $\begin{array}{l}\text { Provisions under } \\
\text { Sauth African } \\
\text { Arbitration Law }\end{array}$ & $\begin{array}{l}\text { Article 21(2): If any parties, although duly summoned, fails to appear without a } \\
\text { valid excuse, the Arbitral Tribunal has the power to proceed with the hearing. }\end{array}$ \\
\hline $\begin{array}{l}\text { Provisions under } \\
\text { China } \\
\text { Arbitration Law }\end{array}$ & $\begin{array}{l}\text { UNCITRAL Article 30: If within a period of time fixed by the UNCITRAL } \\
\text { Rules or the Arbitral Tribunal: (1): The Claimant has failed to communicate } \\
\text { its Statement of Claim, the Arbitral Tribunal shall issue and order terminating the } \\
\text { Arbitral proceedings, unless there are other remaining matters, such as a counter } \\
\text { claim. (2): The Respondent has failed to communicate its response to the Notice } \\
\text { of } \\
\text { Arbitration or its Statement of Defence, the Arbitral Tribunal shall order the } \\
\text { proceedings to continue, without treating such failure as an admission of the } \\
\text { Claimant's allegations. } \\
\text { UNCITRAL Article } 30(2) \text { : If a party, duly notified under the Rules, fails to } \\
\text { appear at a hearing, without showing sufficient cause for such failure, the } \\
\text { Arbitral Tribunal may proceed with the arbitration. } \\
\text { UNCITRAL Article 30(3): If a party, duly invited by the Arbitral Tribunal to } \\
\text { produce documents, exhibits or other evidence, fails to do so within the } \\
\text { established period of time, without showing sufficient cause for such failure, the } \\
\text { Arbitral Tribunal may make an award on the evidence before it. }\end{array}$ \\
\hline $\begin{array}{l}\text { Provisions under } \\
\text { U.S.A. } \\
\text { Arbitration Law }\end{array}$ & $\begin{array}{l}\text { Rule 17.8: If the Claimant fails within the time specified to submit its Statement } \\
\text { of Claim, the Tribunal may issue an order for the termination of the Arbitral } \\
\text { Proceedings or give such other directions as may be appropriate. } \\
\text { Rule 17.9: If the Respondent fails to submit a Statement of Defence, or if at any } \\
\text { point any party fails to avail itself of the opportunity to present its case in a } \\
\text { manner directed by the Tribunal, the Tribunal may proceed with the arbitration. } \\
\text { Rule 21.3: If any party to the proceedings fails to appear at a hearing without } \\
\text { showing sufficient cause for such failure, the Tribunal may proceed with the } \\
\text { arbitration and may make the award based on the submissions and evidence } \\
\text { before it. }\end{array}$ \\
\hline
\end{tabular}

BASIS- 7-

\begin{tabular}{|c|c|}
\hline & Basis for difference: \\
\hline & Appeal \\
\hline $\begin{array}{l}\text { Provisions } \\
\text { under } \\
\text { UNCITRAL } \\
\text { LAW }\end{array}$ & $\begin{array}{l}\text { Article 34(2): All awards shall be made in writing and shall be final and binding on } \\
\text { all parties. }\end{array}$ \\
\hline $\begin{array}{l}\text { Provisions } \\
\text { under Law } \\
\text { Indian } \\
\text { Arbitration } \\
\text { Law }\end{array}$ & $\begin{array}{l}\text { As per the provisions of section } 37,50 \& 59 \text { of the Arbitration and conciliation } \\
\text { Act, 1996, an appeal shall lie from the following orders ( and from no others) to the } \\
\text { court authorized by law to hear appeals from original decress of the court passing } \\
\text { the order. }\end{array}$ \\
\hline $\begin{array}{l}\text { Provisions } \\
\text { under }\end{array}$ & HKIAC Article 30.2: Awards shall be final and binding. \\
\hline
\end{tabular}




\begin{tabular}{|l|l|}
\hline $\begin{array}{l}\text { Hongkong } \\
\text { Law }\end{array}$ & \\
\hline $\begin{array}{l}\text { Provisions } \\
\text { under } \\
\text { Singapore } \\
\text { Arbitration } \\
\text { Law }\end{array}$ & $\begin{array}{l}\text { Rule 28.9: The award shall be final and binding on the parties from the date it is } \\
\text { made. }\end{array}$ \\
\hline $\begin{array}{l}\text { Provisions } \\
\text { under Sauth } \\
\text { African } \\
\begin{array}{l}\text { Arbitration } \\
\text { Law }\end{array}\end{array}$ & $\begin{array}{l}\text { Article 28(6): All awards shall be binding on the parties. By submitting the dispute } \\
\text { to arbitration under these Rules, the parties undertake to carry out any Award } \\
\text { without delay and shall be deemed to have waived their right to any form of } \\
\text { recourse. }\end{array}$ \\
\hline $\begin{array}{l}\text { Provisions } \\
\text { under China } \\
\text { Arbitration } \\
\text { Law }\end{array}$ & $\begin{array}{l}\text { UNCITRAL Article 34(2): All awards shall be made in writing and shall be final } \\
\text { and binding on all parties. }\end{array}$ \\
\hline $\begin{array}{l}\text { Provisions } \\
\text { under U.S.A. } \\
\text { Arbitration } \\
\text { Law }\end{array}$ & $\begin{array}{l}\text { Rule 28.9: The award shall be final and binding on the parties from the date it is } \\
\text { made. }\end{array}$ \\
\hline
\end{tabular}

BASIS- 8-

\begin{tabular}{|c|c|}
\hline & Basis for difference: \\
\hline & Enforcement of Awards \\
\hline $\begin{array}{l}\text { Provisions } \\
\text { under } \\
\text { UNCITRAL } \\
\text { LAW }\end{array}$ & $\begin{array}{l}\text { Article 34(6): An award shall be deemed to be enforced when the copies of the } \\
\text { award signed by the arbitrators shall be communicated to the parties by the Arbitral } \\
\text { Tribunal. }\end{array}$ \\
\hline $\begin{array}{l}\text { Provisions } \\
\text { under Law } \\
\text { Indian } \\
\text { Arbitration } \\
\text { Law } \\
\end{array}$ & $\begin{array}{l}\text { As per the provisions of section } 35,36,48,49,55,57 \& 58 \text { of the Arbitration and } \\
\text { conciliation Act, } 1996 \text { where the court is satisfied that the foreign award is } \\
\text { enforceable, the award shall be deemed to be a decree of that court. }\end{array}$ \\
\hline $\begin{array}{l}\text { Provisions } \\
\text { under } \\
\text { Hongkong } \\
\text { Arbitration } \\
\text { Law }\end{array}$ & $\begin{array}{l}\text { HKIAC Article 30.4: An award shall be deemed to be enforced when the award } \\
\text { must be signed by all of the arbitrators. } \\
\text { HKIAC Article 30.5: An award shall be affixed with the seal of the HKIAC.. }\end{array}$ \\
\hline $\begin{array}{l}\text { Provisions } \\
\text { under } \\
\text { Singapore } \\
\text { Arbitration } \\
\text { Law }\end{array}$ & $\begin{array}{l}\text { Rule 28.6: An award shall be deemed to be enforced when the award shall be } \\
\text { delivered to the Registrar, who shall transmit certified copies to the parties upon the } \\
\text { full settlement of the costs of arbitration. }\end{array}$ \\
\hline $\begin{array}{l}\text { Provisions } \\
\text { under Sauth } \\
\text { African } \\
\text { Arbitration } \\
\text { Law }\end{array}$ & $\begin{array}{l}\text { Article 27(1): Before signing any Award, the Arbitral Tribunal shall submit a draft } \\
\text { form to the Court. The Award is not rendered by the Arbitral Tribunal until it has } \\
\text { been approved by the Court. } \\
\text { Article 28(1): Once an Award has been made, the Secretariat shall notify the parties } \\
\text { of the decision of the Arbitral Tribunal. }\end{array}$ \\
\hline
\end{tabular}




\begin{tabular}{|l|l|}
\hline $\begin{array}{l}\text { Provisions } \\
\text { under }\end{array}$ & $\begin{array}{l}\text { Rule 6(2): The Arbitral Tribunal shall furnish the Director of the board of arbitrators } \\
\text { with a signed copy of the award made by it, including any interim or interlocutory } \\
\text { award. } \\
\begin{array}{l}\text { Arbitration } \\
\text { Law }\end{array}\end{array}$ \\
$\begin{array}{l}\text { Provisions } \\
\text { under }\end{array}$ & $\begin{array}{l}\text { Article 26.5: The sole arbitrator or chairman shall be responsible for delivering the } \\
\text { award to the tribunal, which in turn will transmit certified copies to the parties } \\
\text { U.S.A. }\end{array}$ \\
$\begin{array}{l}\text { Arbitration } \\
\text { Law }\end{array}$ & \\
\hline
\end{tabular}

\section{Detail Comparative Analysis of Indian arbitration law with other countries' arbitration laws:}

\section{- United States of American arbitration law compare to Indian arbitration law}

The Federal Arbitration $\mathrm{Act}^{3}$ (hereinafter referred to as the "FAA") governs arbitrations conducted at the federal level, in the United States. Unlike most jurisdictions with robust arbitration regimes, the FAA is not structured on the UNCITRAL Model Law, as the United States has not adopted the Model Law at the federal level. ${ }^{4}$ In addition to the FAA, several states have adopted independent arbitration statutes pertaining to international commercial arbitration. However, the focus of the present section is limited to the FAA and its role in expediting arbitration proceedings in the US.

The FAA strongly enforces a presumption in favour of arbitral awards, thereby drastically limiting the grounds for appeal against such awards. ${ }^{5}$ As such, the review of arbitration awards is extremely limited, so as to ensure effective settlement of disputes, and ensure inexpensive and swift arbitration. Pertinent to this discussion is the fact that unlike the Indian arbitration regime, the FAA, does not allow judicial review for an 'error of law' committed by the tribunal. The FAA provides limited grounds for setting aside of an arbitral award ${ }^{6}$, viz award procured by corruption, fraud or undue means, evident partiality or corruption in the arbitrators or arbitrators exceeding, or imperfectly executing their powers. Despite no express stipulation in the said legislation, US case law introduced an additional factor, namely 'manifest disregard of law', which could result in the setting aside of an arbitral award. ${ }^{7}$ This additional ground would only be applicable to situations where the arbitrators' findings are more than an error or misunderstanding of law. ${ }^{8}$ However, the US Supreme Court has subsequently held that the grounds for vacating an arbitral award are exclusive, as listed under Section 10 of the FAA. ${ }^{9}$ This contextual background shows the contradistinction between the Indian and American legal regimes governing arbitration. The Arbitration and Conciliation Act, 1996, and related jurisprudence, have been critiqued for allowing excessive judicial intervention. ${ }^{10}$ The Law Commission of India has also advised on the need to balance out the scope of judicial intervention, in order to make the judiciary a vital institution reinforcing arbitration, rather than impeding its growth. The proposed amendments to the Arbitration and Conciliation Act, 1996, which have been elaborately discussed in the subsequent sections, inter alia aim towards ensuring this balance. ${ }^{11}$

\footnotetext{
${ }^{3}$ Federal Arbitration Act, (codified at 9 U.S.C. § 1)

${ }^{4}$ 'Commercial Arbitration: United States', available at <http://globalarbitrationreview.com/know how/topics/61/jurisdictions/23/unitedstates/>, accessed on October 12, 2015

${ }^{5}$ Brentwood Medical Associates v. United Mine Workers, 396 F.3d 237, 241 (3d Cir. 2005)

${ }^{6}$ Section 10 of the Federal Arbitration Act.

7 Devrim Deniz Celik, 'Judicial Review under the UK and US Arbitration Acts: Is Arbitration a Better Substitute for Litigation', IALS Student Law Review | Volume 1, Issue 1, Autumn 2013 available at <http://sas-space.sas.ac.uk/5237/1/1702-2275-1PB.pdf>, accessed on October 12, 2015.

${ }^{8}$ Merrill Lynch, Pierce, Fenner \& Smith Inc. v. Bobker, 808 F.2d 930, 933 (2d Cir. 1986).

${ }^{9}$ Hall Street Associates v. Mattel Inc. 128 S.C. 1396 (2008)

10 246th Law Commission of India Report, Amendments to the Arbitration and Conciliation Act, 1996, August 2014, available at <http://lawcommissionofindia.nic.in/reports/reports216onwards.htm>, visit on Oct. 10,. 2015.

11 Amendments to the Arbitration and Conciliation Bill, 2015, Press Information Bureau, available at <http://pib.nic.in/newsite/PrintRelease.aspx?relid=126356>, visited on Oct. 1, 2015.

DOI: 10.9790/0837-2204023245 www.iosrjournals.org $\quad 40 \mid$ Page
}




\section{- United Kingdom's arbitration law compare to Indian arbitration law}

Unlike the United States, the English arbitration regime is more congruent to Indian law; both of them structured on lines of the UNCITRAL Model Law. The Arbitration Act, 1996, establishes a broader scope of judicial review, thereby reinforcing the normative mandate to the arbitrator correctly applying English law. ${ }^{12}$ Though the grounds for appeal against an arbitral award are similar to the US FAA, their enforcement is more liberal. The fundamental basis of the English regime governing arbitration is to ensure accuracy of arbitral awards when the governing law is English law. Additionally, the Arbitration Act, 1996 also emphasizes greatly on party autonomy. An interesting specimen of the latter is a recent judgment of the Supreme Court in Jivraj v. Hashwani. ${ }^{13}$ An appeal herein challenged the order passed by the Court of Appeal, which had held that arbitrators were subject to the same anti-discrimination laws applicable to employees in the UK; therefore, any arbitration agreement or clause mandating an arbitrator to be of a particular religion or belief, was unenforceable. The Supreme Court reversed this decision upholding that validity of such arbitration agreements imposing faith or nationality qualifications on the choice of arbitrators, thereby reinforcing the principle of 'party autonomy'.

With respect to the scope and threshold of judicial intervention, a major difference between the arbitration regimes in the US and the UK is the legislative permissibility of setting aside of an award, because of an 'error of law', in the latter. ${ }^{14}$ The Arbitration Act, 1996 allows three grounds to challenge an arbitral award want of jurisdiction, serious irregularity and error of law. In fairness, it should be noted that though the judiciary has been afforded greater latitude to intervene in the arbitration process, the English regime prioritizes preserving the nature of arbitration as an expeditious dispute resolution mechanism. The law inter alia imposes a strict time bar of 28 days from the date of the award to challenge it, and not giving leave to appeal when there is merely a suspicion about the accuracy of the award on the point of law. Given Indian legal system's foundation in common law, a parallel analysis evaluating its merit qua the English arbitration regime is warranted. That said, reiterating the aforementioned comment, the English system is quite similar to the Indian arbitration mechanism; especially with respect to the degree and standard of judicial review of awards. India can however, adopt the liberal approach of ensuring high standards of neutrality of arbitrators, party autonomy, and adherence to time frames provided under the Arbitration Act, 1996, to ensure a speedy process. The amendments to the Arbitration and Conciliation Act, 1996, are a step in this direction.

\section{- Singapore's arbitration law compare to Indian arbitration law}

Singapore provides a bifurcated mechanism for conducting arbitrations - while international arbitrations ${ }^{15}$ are subject to the International Arbitration Act, the remaining 'non-international' arbitrations not covered there under, are subject to the Arbitration Act. ${ }^{16}$ Like India, Singapore's law follows the UNCITRAL Model Law; in fact, the International Arbitration Act actually gives the Model Law (except Part VIII thereof), the force of law in Singapore. ${ }^{17}$ Singapore's switch to the Model Law also traces a similar course, as was traversed by Indian law governing commercial arbitration, both domestic and international.

Despite having a common normative basis, the significant difference between Indian and Singaporean legal regimes governing arbitration is the extensive flexibility available to parties to choose their preferred legal regime. Unlike India, parties to a non-international arbitration, with its seat in Singapore, are at liberty to 'opt in' to the procedure established under their International Arbitration Statute, instead of the local Arbitration Act. Exercising this option would place such an arbitration under a procedure where judicial intervention and

\footnotetext{
12 Devlik Celik, [f.n. 5, at Pg. 21].

13 [2011] UKSC 40

${ }^{14}$ Section 69(1) of the Arbitration Act 1996

${ }^{15}$ Section 5(1) of the International Arbitration Act. It is pertinent to mention that in addition to international arbitrations, as defined under Section 5(2) of the said Act, a non-international arbitration may also 'opt in' to be governed by the International Arbitration Act.

${ }^{16}$ Section 3 of the Arbitration Act. All arbitrations conducted pursuant to agreements considered 'domestic', or where the seat of arbitration is Singapore to whom Part II of the International Arbitration Act does not apply, are governed by the Arbitration Act.

${ }^{17}$ Section 3(1) of the International Arbitration Act.
} 
oversight are limited. ${ }^{18}$ Conversely, an international arbitration seated in Singapore can 'opt out' of the International Arbitration Act. ${ }^{19}$ The parties can do so by stipulating in the arbitration agreement that it be governed by the Arbitration Act, which would ensure a greater degree of court supervision. With the introduction of SIAC and the SIAC rules, institutional arbitration in Singapore has become the popular mode of arbitrating disputes. The development of SIAC has occurred parallel to Singapore emerging as a vital hub of commercial and financial activities. An expedited and definitive dispute resolution mechanism has boosted Singapore's global viability thereby, making it one of the most popular commercial arbitration seats. ${ }^{20}$ Given the Indian government's ambition to ease the ability of conducting business in India, a crucial leaf can be taken from Singapore's book, especially with respect to the revamping and modernizing of the arbitration regime.

\section{The Arbitration and Conciliation (Amendment) Act, 2015: An analysis for the improvement in International Commercial Arbitration (ICA) in India}

Since a long period, arbitration has become the default choice for adjudication of commercial disputes. In India, this is true even with respect to purely domestic disputes, as trials in courts take significantly longer due to huge pendency. However, over the last two decades, the process of arbitration - in particular in ad hoc domestic disputes - had come to look more like the traditional court proceedings in India. Combined with high costs due to a small pool of qualified and trusted arbitrators, there has been a growing sense of exasperation amongst the users of the process. An amendment to the law to remedy some of these issues, and others such as misinterpretation of certain provisions that invariably crop up in the life of any legislation had been on the cards for quite some time. After two aborted attempts - one in 2001 and the other in 2010 - the law has finally been amended in 2015.The Ordinance carries forward most proposals of the 246th Law Commission Report released last year, but also introduces some unique provisions not hitherto seen in any leading arbitration statute. Some of these provisions provide some extraordinary measures to remedy certain peculiar issues with ad hoc domestic arbitration including the time limit for completing arbitration and arbitrators fees.

The Ordinance mandates that every arbitration seated in India must result in an award within 12 months of the arbitral tribunal being constituted, with parties having the right to extend this by another 6 months through mutual consent. If this does not happen, the mandate of the tribunal terminates - unless the Court extends it imposing such conditions as it deems fit. The Court can also penalize arbitrators by ordering reduction of their fees at the time of granting such extension. It can, if it considers fit, substitute one or all the arbitrators at the time of granting extension. The Ordinance also suggests many other changes of far reaching consequence some affecting a significant departure from the existing law, some clarifying certain controversies, and others simply confirming the law as declared through interpretations received from courts over time.

Three changes in particular are of great consequence to international businesses - first, foreign parties are no longer required to litigate in lower courts in remote corners of this vast country with High Courts now becoming the court of first instance for all purposes relating to international arbitration; second, provisions relating to interim measures from courts and seeking court assistance in taking evidence have been extended to foreign seated arbitrations; and third, the removal of 'patent illegality' as a ground to challenge awards arising out of international arbitration seated in India.

\footnotetext{
18 Lawrence, G.S. Boo, 'The Law and Practice of Arbitration in Singapore', available at <http://www.aseanlawassociation.org/docs/w4_sing1.pdf>, accessed on October 12, 2015. See also, Section 5(2) International Arbitration Act, [f.n. 13].

${ }^{19}$ Section 15(1) of the International Arbitration Agreement.

${ }^{20}$ Lawrence, [f.n. 16, at Pg. 166].
} 


\section{* Analysis of the recommendation suggested by the 246th Law Commission Report}

Amendment suggested by the Law Commission has been adopted. This amendment codifies the position taken by the Supreme Court in TDM Infrastructure Pvt. Ltd. vs. UE Development India Pvt. Ltd. ${ }^{21}$ and reaffirmed in subsequent decisions by the courts.

An opportunity has been missed to introduce another criterion, i.e. subject matter of the contract, as relevant to determine whether an arbitration should be considered 'international'. The Act had omitted that criterion while adopting the definition from the UNCITRAL Model Law on International Commercial Arbitration ("Model Law"). In light of the amount of international work that Indian companies have been doing in recent times - and particularly in light of the default position under private international law which considers 'subject matter' relevant - two Indian parties should be allowed to choose a foreign law and seat if the subject matter of the contract is not Indian. In absence of such provision, it is possible a much wider and unsound interpretation will find its way in on the issue of two Indian parties' freedom to choose a seat outside India - as has recently happened in the Sassan Power Ltd. vs. North American Coal Corporation India Pvt. Ltd. ${ }^{22}$

\section{THE ARBITRATION AND CONCILATION (PROPOSED AMENDMENT) ACT,}

\section{INTRODUCTION}

Dispute settlement is a fundamental aspect of an ideal legal system, wherein arbitration plays a prominent role. After an exhaustive analysis of Indian Law Commission report $246^{\text {th }}$, The Arbitration and Conciliation Act, 1996 \& The Arbitration and Conciliation (Amendment) Act, 2015 and the opinions obtained by the commercial experts, following modality may be put forward in the form of proposed amendments to the existing Act.

In order to expedite the International commercial arbitration process and encourage ease of doing business in India the present proposed Amendment Act, has been made to resolve the issues involving in International commercial arbitration and to make India as a hub for International commercial arbitration.

\section{STATEMENT OF OBJECT AND KEY FINIDINGS}

* The applicability of part I in reference to part II, especially for the legal issues under International commercial arbitration are clearly defined.

* The amendment makes the provisions of Section 2, 9, 34, 37 \& 48 of the Act, applicable even if the Arbitration is seated outside India.

* The proposed amendment ensures speedy disposal of proceedings by stating the International commercial arbitration shall cover under Section 9 for the disposal of disputes within 90 days.

* By virtue of the proposed amendments , not only parties to the International commercial arbitration, but any person claiming through or under any party to International commercial arbitration can seek protection under Indian arbitration laws.

* Definition of public policy under section 34 \& 48 shall clearly apply in case of International commercial arbitration.

* Filing of an objection under section 34 for International commercial arbitration would not ipso facto stay the enforceability of foreign Awards. Parties challenging in the foreign Awards will have to seek an stay against the enforceability of the foreign Awards from the Court by filing a separate application in this regard.

${ }^{21}$ (2008) 14 SCC 271

${ }^{22}$ First Appeal No. 310 of 2015] case, High Court of Madhya Pradesh, 


\section{THE ARBITRATION AND CONCILATION (PROPOSED AMENDMENT) ACT,}

\section{An Act to amend the Arbitration and Conciliation Act, 1996.}

1. Short title and commencement.-(1) This Act may be called the Arbitration and Conciliation (Proposed Amendment) Act,

(2) It shall be deemed to have come into force on the date it adopted or accepted by the legislature.

2. Amendment of section 2-In the Arbitration and Conciliation Act, 1996( 26 of 1996) \& Arbitration and Conciliation (Amendment) Act, 2015 ( 3 of 2016) (hereinafter referred to as the principal Act), in section $2,-$

(I) in sub section (1) Clause (e) (ii) shall be substituted, namely:-

in the case of International commercial arbitration, the Indian council of Arbitration (ICA) or International centre for Alternative Dispute Resolution (ICADR) having jurisdiction to decide the questions forming the subjectmatter of a case, and in other cases Supreme Court having jurisdiction to hear appeals against the foreign awards.

Explanation- In case of foreign Awards passed under International commercial arbitration the regulatory bodies like ICA \& ICADR shall have jurisdiction to deal with the issues involve under International commercial arbitration. Likewise in all above cases Hon'ble Supreme Court having jurisdiction to hear appeals against the foreign awards.

(II) In sub-section ( 2), the following proviso shall be inserted, namely:-This part shall apply where the place of arbitration in India as well as in International commercial arbitration specially in matters relating to interim measures, court assistance, setting aside and for appeal against the foreign Awards.

Explanation- The applicability of the part for certain issues involving International commercial arbitration, which seeks some protective measures for the Award which has been passed even by the foreign seated tribunal. This provision somehow clear the ambiguities relating to the application of such provisions in International commercial arbitration specially in matters relating to interim measures, court assistance, setting aside and for appeal because the proposed amendment would make the provisions of section 7,27, 34, 37 of the principal Act applicable even in case of International commercial also.

3. Amendment of section 9- Insertion of new section as sub section 9(1A) namely:- The provisions relating to interim measures, etc. by court shall apply in International commercial arbitration also.

Explanation- This proposed amendment would make a feasible environment for foreign investors especially for some interim measures in case of International commercial arbitration, which may ensure the protection to them. By virtue of this amendment, not only the parties to an International commercial arbitration, but any person claiming through or under any party to International commercial arbitration can seek reference of the dispute to arbitration.

4. Amendment of section 27- Insertion of new section as sub section 27(7) namely:-

The provisions relating to court assistance in taking evidence may also apply in case of International commercial arbitration.

Explanation- This proposed amendment would make a favorable environment for the foreign investors especially for the court assistance in taking evidence in case foreign Awards under International commercial arbitration. This proposed amendment will also helpful in trust building amongst the foreign investors as well reduce the insecurity relating to International commercial arbitration in India. 
5. Amendment of section 34- Insertion of new clause as sub section 34(2)(iii) namely:-

The provisions relating to setting aside an Award shall also apply in case of International commercial arbitration.

Explanation- The term 'Public policy' of India defined under section 48 of the principal Act, in terms of conflict of laws between the state parties to the International commercial arbitration must also cover under this section as well this is the conflicting major issue under International commercial arbitration.

6. Amendment of section 37-Insetion of new sub section as section 37 (4) namely:- The provision of section 37 for appeal shall also applicable against the foreign awards in case of International commercial arbitration in reference to the proposed amendments made under section 2(2) of this Act.

Explanation- Appeal against the foreign awards under International commercial arbitration has been an argumentative issue for the International Commercial communities. Especially in India it has been experienced that because of lake of proper mechanisms for appeal against the foreign seated awards Indian arbitration law could not get recognition as a hub for International commercial arbitration. This new sub section somehow protect the investors rights under International trade and commerce against the legal issues covered under International commercial arbitration.

7. Amendment of section 48-The provisions of this sections shall be placed in part II of the existing Act as it is related with International commercial arbitration.

\section{Conclusion}

It is said that the parties are the masters of the arbitration but in institutional arbitration, the institutions virtually acquire certain powers of the parties' such as appointment of arbitrators, etc. and are in a position to impose their will upon the parties. This seems to be against the very spirit of arbitration and one may say that this is not arbitration in the true sense. Though ad hoc arbitration would then be preferred, it can be argued that in today's modern and complex commercial world, ad hoc arbitration is suitable only to disputes involving smaller claims and less affluent parties and to domestic arbitrations One may quote in support thereof that "Whatever its merits in a purely domestic situation, ad hoc arbitration in an international setting frequently frustrates the party seeking to enforce the contract". In the context of international commercial disputes, one may argue that institutional arbitration is more suitable, even though apparently it is more expensive, time consuming and rigid than ad hoc arbitration, keeping in mind the fact that it provides established \& updated arbitration rules, support, supervision \& monitoring of the arbitration, review of awards and most importantly, strengthens the credibility of the awards. The changes incorporated in the Arbitration and Conciliation (Proposed Amendment) Act, will not only remedy the malady but also seek to set up the stage for arbitration in India to achieve a higher plane of growth. The amendments will certainly impart confidence to foreign investors and is a step in the right direction to make India as a hub for International commercial arbitration. 